\title{
Short-term grazing exclusion has no impact on soil properties and nutrients of degraded alpine grassland in Tibet, China
}

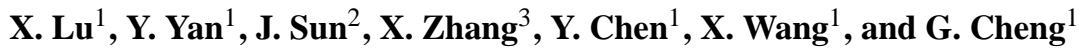 \\ ${ }^{1}$ Key Laboratory of Mountain Surface Processes and Ecological Regulation, Institute of Mountain Hazards and Environment, \\ Chinese Academy of Sciences, Chengdu 610041, China \\ ${ }^{2}$ Key Laboratory of Ecosystem Network Observation and Modeling, Chinese Academy of Sciences, Beijing 100101, China \\ ${ }^{3}$ School of Public Administration, Hohai University, Nanjing 210098, China \\ Correspondence to: Y. Yan (yy@imde.ac.cn)
}

Received: 13 August 2015 - Published in Solid Earth Discuss.: 26 August 2015

Revised: 26 October 2015 - Accepted: 27 October 2015 - Published: 5 November 2015

\begin{abstract}
Since the 1980s, alpine grasslands have been seriously degraded on the Tibetan Plateau. Grazing exclusion by fencing has been widely adopted to restore degraded grasslands. To clarify the effect of grazing exclusion on soil quality, we investigated soil properties and nutrients by comparing free-grazing (FG) and grazing exclusion (GE) grasslands in Tibet. Soil properties - including soil bulk density, $\mathrm{pH}$, particle size distributions, and proportion of aggregates showed no significant difference between FG and GE plots. Soil organic carbon, soil available nitrogen, and available phosphorus contents did not differ with grazing exclusion treatments in both the $0-15$ and $15-30 \mathrm{~cm}$ layer. However, soil total nitrogen and total phosphorus contents were remarkably reduced due to grazing exclusion at $0-15 \mathrm{~cm}$ depth. Furthermore, growing season temperature and/or growing season precipitation had significant effects on almost all soil property and nutrient indicators. This study demonstrates that grazing exclusion had no impact on most soil properties and nutrients in Tibet. Additionally, the potential shift of climate conditions should be considered when recommending any policy designed for restoration of degraded soil in alpine grasslands in the future. Nevertheless, because the results of the present study come from a short-term (6-8 years) grazing exclusion, the assessments of the ecological effects of the grazing exclusion management strategy on soil quality of degraded alpine grasslands in Tibet still need long-term continued research.
\end{abstract}

\section{Introduction}

Soil is a key resource that contributes to the Earth system functioning as a control and manages the cycles of water, biota and geochemicals (Keesstra et al., 2012; ParrasAlcántara et al., 2013; Brevik et al., 2015). Unreasonable human management of the soil resources is resulting in land degradation due to soil erosion, soil organic matter exhaustion, loss of soil structure, pollution, forest fires or deforestation (Cerdà et al., 2009; Novara et al., 2011, 2013; GarcíaOrenes et al., 2012; Pereira et al., 2013; Zhao et al., 2013; Keesstra et al., 2014). This is why there is a need to restore and rehabilitate soils as a source of nutrients and services to humankind (Bai et al., 2013; Mekonnen et al., 2015a, b; Roa-Fuentes et al., 2015; Tejada and Benítez, 2014). Grazing is one of those human uses of the land that will degrade or not degrade the soils and the land dependent upon the right management (Costa et al., 2015; Papanastasis et al., 2015; Tarhouni et al., 2015).

Grazing exclusion from the creation of large-scale enclosures has become a common management strategy to prevent grassland degradation and sustain grassland ecosystem function by the restoration of degraded vegetation and improvement of soil quality throughout the world in recent decades (Medina-Roldán et al., 2012; Wu et al., 2010; Mofidi et al., 2013). Previous studies examining the effect of grazing exclusion on grassland have primarily investigated the vegetation productivity, plant species and communities (Gonzales and Clements, 2010; Schultz et al., 2011). Nevertheless, soil also plays an important role in supplying organic matter and 
cycling nutrients, such as nitrogen and carbon; it could also directly affect vegetation productivity, community composition and plant species richness during the grassland restoration succession process. Information on these aspects is required for a better understanding of the restoration mechanisms and the biological feedback of grassland degradation, and for appropriate management and conservation of grassland (Su et al., 2005; Pulido-Fernández et al., 2013; Mekuria and Aynekulu, 2013).

Some studies have shown grazing exclusion to be associated with several soil physical property variations (Greenwood and McKenzie, 2001; Hoshino et al., 2009; MedinaRoldán et al., 2012; Mofidi et al., 2013). For instance, soil bulk density (BD) was found to be lower in grazing exclusion grassland compared to freely grazed grassland due to the elimination of soil trampling by livestock (Gao et al., 2011), as well as the increase of root biomass accumulation (Yuan et al., 2012). The soil particle size distribution revealed that grazing exclusion led to greater silt and clay content, and lower sand content under non-grazed grasslands (Chen et al., 2012; Mofidi et al., 2013). In addition, grassland with grazing exclusion has higher water-holding capacity, total porosity and infiltration rates; consequently, soil moisture is higher in non-grazed grassland (Yuan et al., 2012; Haynes et al., 2014). In general, soil physical properties improved after grazing exclusion due to natural amelioration of the soil structure. Biological activity due to the growth and decay of plant roots, the activity of soil-dwelling animals, and the wetting-and-drying cycles were the probable mechanisms causing this natural amelioration (Mofidi et al., 2013; L. Wen et al., 2013).

Nevertheless, research results with regard to the effect of grazing exclusion on soil nutrients were not consistent. For instance, soil organic carbon in the surface soil under grazing exclusion conditions was reportedly increased in a semiarid woody rangeland (22 years of grazing exclusion) in the Zagros Mountains, central Iran (Raiesi and Riahi, 2014), decreased in a montane Kobresia winter pasture (7 years of grazing exclusion) on the north-eastern Tibetan Plateau (Hafner et al., 2012), and showed no change in an upland grassland (7 years of grazing exclusion) in northern England (Medina-Roldán et al., 2012) and in a semiarid sagebrush steppe (40 years of grazing exclusion) in Fremont County of Wyoming, USA (Shrestha and Stahl, 2008). Soil available phosphorus was significantly greater in grazing exclusion grassland of the Imam Kandi Rangelands, Iran (Mofidi et al., 2013), and the semiarid rangeland in the northern highlands of Ethiopia (Mekuria and Aynekulu, 2013), but it was not significantly changed in the desertified sandy grassland of Inner Mongolia, China ( $\mathrm{Li}$ et al., 2011), and the subalpine grasslands of the Swiss National Park (Haynes et al., 2014). These results imply a lack of clear relationship between grazing exclusion and soil nutrients, which may result from the contributions of different grassland ecosystem types (Luan et al., 2014), inconsistent years of grazing exclusion (Wang et al., 2010; Gao et al., 2011), soil heterogeneity (Mekuria and Aynekulu, 2013), and different environmental conditions (Raiesi and Riahi, 2014).

Alpine grasslands of the Tibetan Plateau, which are the most expansive areas of alpine grassland in the world, have undergone serious regional degradation in the past 3 decades due to a combination of global climate change, rapidly increasing grazing pressure, rodent damage and other factors (Harris, 2010). In response to the problem of grassland degradation on the Tibetan Plateau, China's state and local authorities initiated a program in 2004 called the "retirelivestock-and-restore-grassland" policy. This campaign has focused mostly on grazing exclusion by fencing as an approach to recover the degraded rangelands and to prevent new degradation (Wei et al., 2012). This program has been in progress for more than 10 years, although, with an increasing number of studies of grazing exclusion effects on soil properties of alpine grassland ecosystems, greater emphasis has been placed on a single alpine grassland type - the alpine meadow (Wu et al., 2010; Dong et al., 2012; Li et al., 2013) - and usually at one experimental or investigation site (Gao et al., 2011; Hafner et al., 2012; Shi et al., 2013).

In the present study, three alpine grassland types in nine counties were selected to investigate the effects of grazing exclusion on the soil quality of degraded alpine grasslands in Tibet. We contrast free-grazing and grazing exclusion treatments to address the following questions: (1) how does grazing exclusion affect the soil quality, evaluated by soil properties and nutrients, in alpine grassland of Tibet? and (2) does the soil property and nutrient response to grazing exclusion differ among different alpine grassland types? On the basis of the removal of soil trampling by livestock and the probable increase of litter biomass accumulation with grazing exclusion (Wang et al., 2010), we hypothesized that soil properties and nutrients would improve in the absence of grazing. Based on different plant species diversity and community structure, vegetation productivity and cover, and environmental conditions (J. Wu et al., 2014), we further hypothesized that soil property and nutrient responses to the absence of grazing would differ among different alpine grassland types.

\section{Materials and methods}

\subsection{Study area}

Tibet is located between $26^{\circ} 50^{\prime}$ and $36^{\circ} 29^{\prime} \mathrm{N}$ and $78^{\circ} 15^{\prime}$ and $99^{\circ} 07^{\prime} \mathrm{E}$ and covers a total area of more than 1.2 million $\mathrm{km}^{2}$, which is approximately one-eighth of the total land surface of China. Tibet is an important ecological security shelter zone that acts as an integral water reservoir, regulating climate change and water resources in China and eastern Asia. Solar radiation is strong, with annual radiation varying between 140 and $190 \mathrm{kcal} \mathrm{cm}^{-2}$ in different parts of the region and long sunshine hours, with annual sunshine ranging from 


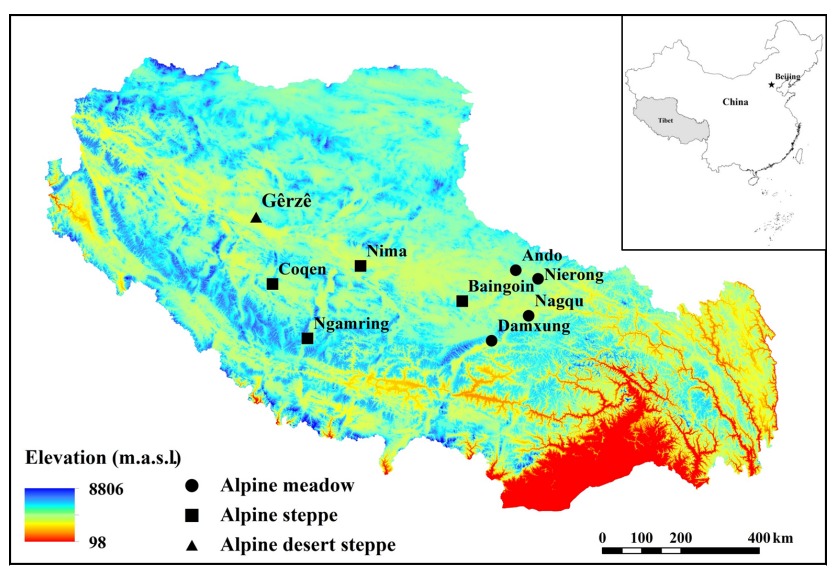

Figure 1. Location of study area and distribution of sampling sites of alpine grassland.

1800 to $3200 \mathrm{~h}$, increasing from the east to the west. Due to geographical conditions and atmospheric circulation, the average annual temperature is rather low with a large diurnal range, and the temperature varies from 18 to $-4{ }^{\circ} \mathrm{C}$ and decreases gradually from the southeast to the northwest. The average annual precipitation is less than $1000 \mathrm{~mm}$ in most areas of Tibet, reaching $2817 \mathrm{~mm}$ in the east and decreasing to approximately $70 \mathrm{~mm}$ in the west (Dai et al., 2011).

Alpine grasslands are the most dominant ecosystems in Tibet, covering more than $70 \%$ of the whole plateau's area. Alpine steppe is the most common grassland type in Tibet; it is composed of drought-tolerant perennial herbs or small shrubs under cold and arid or semiarid climate conditions, which represent approximately $38.9 \%$ of the total Tibetan grassland area. Alpine meadow is the second-largest grassland type and is composed of perennial mesic and mesoxeric herbs under cold and wet climate conditions, occupying approximately $31.3 \%$ of the total grassland area of Tibet. Alpine desert steppe occupies approximately $10.7 \%$ of the total grassland area and is composed by xeric small shrubs and small grasses under cold and arid climate conditions; it is a transitional type of alpine grassland from the steppe to the desert in Tibet (Land Management Bureau of Tibet, 1994).

\subsection{Survey design and sampling}

Since the retire-livestock-and-restore-grassland ecological program started in 2004, more than $2.4 \times 10^{6}$ ha of alpine grasslands in Tibet have been fenced to exclude livestock grazing (Yan and $\mathrm{Lu}, 2015$ ). We conducted a multi-site survey during the peak growing season from late July to midAugust in 2013 in nine counties which represented three of the main natural grassland vegetation types in Tibet, including alpine meadow, alpine steppe and alpine desert steppe (Fig. 1). In these nine counties, grazing exclusion areas, which have been excluded from livestock with metal fences, were established during the years of 2005-2007. Since the establishment of fencing, the fenced grasslands have excluded livestock all year-round, and the metal enclosures were also effective to exclude large wildlife herbivores, such as Pantholops hodgsonii, Procapra picticaudata, and Equus kiang. The adjacently open grassland outside the enclosures was still traditionally grazed by yak and sheep around the year; the actual averaged stocking rate approximately ranges from 0.16 sheep units $\mathrm{ha}^{-1}$ in the western counties to 2.05 sheep units ha ${ }^{-1}$ in the eastern counties for the study region (J. Wu et al., 2013, 2014). In the present study, the enclosed areas inside the fencing were defined as grazing exclusion (GE) plots and the areas outside of the fencing nearby were defined as free-grazing (FG) plots.

At each sample location, three pairs of $0.5 \mathrm{~m} \times 0.5 \mathrm{~m}$ quadrats at each GE and FG treatment sample plots were laid out collinearly at intervals of approximately $20 \mathrm{~m}$. In total, 54 quadrats of alpine grassland in Tibet were sampled, with 27 quadrats ( 9 plots $\times 3$ quadrats) for FG treatments and 27 quadrats for GE treatments. The quadrats of FG plots chosen in this study were well matched with the adjacent GE plots, and both quadrats in GE and FG plots are within $800 \mathrm{~m}$ from the enclosure edges to make sure that each pair of sites was as similar as possible in slope, aspect, and soils. At each quadrat, all aboveground plants and litter were removed from the soil surface before the sampling. Five soil samples were obtained for each quadrat from FG plots and GE plots by bucket auger at two different depths: $0-15$ and $15-30 \mathrm{~cm}$, and five soil samples were mixed as a soil sample for the soil property and nutrient analysis. For the determination of soil bulk density, soil cores $(5.4 \mathrm{~cm}$ in diameter) were also taken from each layer using a stainless-steel cylinder. In addition, the location and elevation of each site were measured using GPS (Garmin MAP62CSX, Garmin Ltd, USA).

\subsection{Soil samples analysis}

Soil BD was sampled from $0-15$ and $15-30 \mathrm{~cm}$ depths using a soil-cutting ring of $5.3 \mathrm{~cm}$ in diameter and then was determined as the moisture-corrected (oven-dried at $105^{\circ} \mathrm{C}$ ) mass of each sample divided by the measured volume of the excavated soil core (Campbell et al., 2014). Prior to soil property and nutrient analyses, roots and litter were removed from the soil samples by hand and then air-dried, crushed, and passed through a $2 \mathrm{~mm}$ mesh sieve. Soil particle size distributions (PSDs) were determined by the pipette method following $\mathrm{H}_{2} \mathrm{O}_{2}$ treatment to destroy organic matter and dispersion of soil suspensions by sodium hexametaphosphate (Su et al., 2010). The proportion of soil aggregates (PM) was also measured by using a pipette method with five aggregate-size classes $(2-0.25,0.25-0.05,0.05-0.02,0.02-$ $0.002,<0.002 \mathrm{~mm}$ ) (Liu, 1996). Soil $\mathrm{pH}$ was determined in soil-water suspensions $(1: 2.5, v / v)$ (Alvarenga et al., 2012). Soil organic carbon (SOC) and soil total nitrogen (TN) contents were determined by using a vario MACRO cube elemental analyzer (Elementar Analysensysteme GmbH, Ger- 
many) (Qu et al., 2014). To remove inorganic carbon, all samples for SOC analysis were acid-treated with hydrochloric acid $(10 \% \mathrm{HCl})$ prior to analysis. Total phosphorus (TP) content was determined using the $\mathrm{NaHCO}_{3}$ alkali digestion method and by molybdenum antimony colorimetry (Cao et al., 2013). Available nitrogen (AN) was determined by using the continuous alkali-hydrolyzed reduction diffusion method (Wang et al., 2013), and available phosphorus (AP) was determined using the Olsen method (Olsen et al., 1954).

\subsection{Climate data}

Monthly meteorological data sets were derived from the China Meteorological Data Sharing Service System (CMDSSS, http://data.cma.gov.cn) with spatial resolutions of $0.5^{\circ}$ from 2005 to 2013 . The data sources include monthly mean temperature and monthly precipitation data from more than 2400 well-distributed climate stations across China, as well as digital elevation model (DEM) data. The meteorological gridded data sets were generated by CMDSSS through the thin plate spline (TPS) method using ANUSPLIN software (ERSI, Redlands, California, USA), and a goodness of fit of the interpolated values was validated by CMDSSS (Shi et al., 2014). The growing season temperature (GST) and growing season precipitation (GSP) were defined as the average air temperature and the accumulated precipitation during the growing season of alpine grasslands from May to September. The GST and GSP from 2005 to 2013 matched with nine sites' locations were extracted from these meteorological raster surfaces in ArcGIS 10.0 (ERSI, Redlands, California, USA) for further analyses.

\subsection{Statistical analysis}

A paired-difference $t$ test was used to test the potential effect of grazing exclusion on each soil property and nutrient indicator. Analysis of covariance (ANCOVA) by the general linear model (GLM) was employed to evaluate the effects of grazing exclusion treatment, soil depth, and climatic factors on each soil property and nutrient indicator of alpine grasslands. In the ANCOVA analysis, the fixed factor was alpine grassland grazing treatments (FG and GE) and soil depth, while the covariates were GST and GSP. Homogeneity of variances and normal distribution of residuals were verified by examining plots of the distribution of residuals and of the residuals against fitted values to fulfill statistical assumptions of ANCOVA. The two covariates, growing season temperature and growing season precipitation, that were used to fit the linear ANCOVA models were not highly correlated with the fixed factor $(P>0.05)$. Pearson's correlation analysis was used to test the relationships among soil property and nutrient indices. The least significant difference test was used to compare the means at $P<0.05$. All statistical analyses were performed using IBM SPSS Statistics 19 software (SPSS/IBM, Chicago, IL, USA).

\section{Results}

\subsection{Soil properties}

Soil BD of alpine grasslands (alpine meadow + alpine steppe + alpine desert steppe) in the $0-15$ and $15-30 \mathrm{~cm}$ soil layers was lower, whereas soil $\mathrm{pH}$ in both soil layers was higher in GE plots than in the FG plots, but the differences were all not significant between GE and FG plots $(P>0.05)$ (Table 1). Among three alpine grassland types, no significant differences in soil BD were observed with GE treatments $(P>0.05)$, except for significantly decreased soil $\mathrm{BD}$ in the $0-15 \mathrm{~cm}$ soil layer of alpine meadow $(P<0.05)$. Soil $\mathrm{pH}$ was significantly altered by the grazing exclusion treatment in the $0-15 \mathrm{~cm}$ layer of the alpine meadow $(P<0.05)$, but it was not significantly altered at the $15-30 \mathrm{~cm}$ depth in alpine meadow and at both soil layers in other two alpine grasslands $(P>0.05)$.

Soil PSDs indicated the alpine grassland soil texture was sandy loam, consisting primarily of sand $(2-0.05 \mathrm{~mm})$. The soil proportion of aggregates (PM) mainly showed aggregate composition sizes of $2-0.25$ and $0.25-0.05 \mathrm{~mm}$ in alpine grassland (Table 1). However, for both PSDs and PM, the mean values of almost all indicators in both soil layers did not differ significantly between GE and FG grasslands $(P>$ 0.05). The results from ANCOVA demonstrate that grazing exclusion, soil depth, and their interaction have no effect on most of soil properties; nevertheless, almost all soil property indicators were significantly impacted by climate factors, GST and/or GSP (Table 2).

\subsection{Soil nutrients}

Grazing exclusion did not significantly affect the soil organic carbon (SOC), soil AN, and soil AP contents in both soil layers $(P>0.05)$, but soil TN and TP at $0-15 \mathrm{~cm}$ depth significantly decreased (15.63 and $12.50 \%$, respectively) due to grazing exclusion treatments $(P<0.05)$ (Fig. 2). Among the three alpine grassland types, grazing exclusion significantly increased SOC and TN contents in the $15-30 \mathrm{~cm}$ layer of the alpine desert steppe, and grazing exclusion significantly decreased soil TP and AP at $0-15 \mathrm{~cm}$ depth in the alpine meadow. Statistical analyses from ANCOVA showed that all soil nutrients - including SOC, TN, TP, AN, and AP - were not significantly impacted by grazing exclusion and soil depth. For the climatic factors, GST had a significant effect on soil TP contents, whereas GSP had a significant effect on SOC, soil TN, and soil AN contents (Table 2).

\subsection{Relationships among soil properties and nutrients}

The relationships among different soil properties and nutrients are shown in Table 3. In general, correlation analyses showed that soil BD was positively correlated with soil sand content $(P<0.01)$ and negatively correlated with soil silt content and most soil nutrient contents $(P<0.01)$. The $2-$ 
Table 1. Statistical comparison of overall mean values of soil properties \pm standard error (SE) at $0-15$ and $15-30 \mathrm{~cm}$ depth using paireddifference $t$ test ( $\alpha=0.05$ ) between free-grazing (FG) plots and grazing exclusion (GE) plots. $P$ values below 0.05 are in bold.

\begin{tabular}{|c|c|c|c|c|c|c|c|c|c|c|}
\hline & \multirow{2}{*}{$\begin{array}{l}\text { Soil } \\
\text { properties }\end{array}$} & \multirow[t]{2}{*}{ Depth } & \multicolumn{2}{|c|}{ Alpine meadow } & \multicolumn{2}{|c|}{ Alpine steppe } & \multicolumn{2}{|c|}{ Alpine desert steppe } & \multicolumn{2}{|c|}{ Alpine grassland } \\
\hline & & & FG & GE & FG & GE & FG & GE & FG & GE \\
\hline & $\mathrm{BD}\left(\mathrm{g} \mathrm{cm}^{-3}\right)$ & $\begin{array}{l}0-15 \mathrm{~cm} \\
15-30 \mathrm{~cm}\end{array}$ & $\begin{array}{l}\mathbf{1 . 3 5} \pm \mathbf{0 . 0 9} \\
1.47 \pm 0.06\end{array}$ & $\begin{array}{l}\mathbf{1 . 1 3} \pm \mathbf{0 . 1 0} \\
1.38 \pm 0.10\end{array}$ & $\begin{array}{l}1.58 \pm 0.03 \\
1.53 \pm 0.06\end{array}$ & $\begin{array}{l}1.61 \pm 0.05 \\
1.60 \pm 0.06\end{array}$ & $\begin{array}{l}1.52 \pm 0.11 \\
1.39 \pm 0.01\end{array}$ & $\begin{array}{l}1.37 \pm 0.10 \\
1.38 \pm 0.06\end{array}$ & $\begin{array}{l}1.47 \pm 0.05 \\
1.49 \pm 0.04\end{array}$ & $\begin{array}{l}1.37 \pm 0.06 \\
1.48 \pm 0.06\end{array}$ \\
\hline & $\mathrm{pH}$ & $\begin{array}{l}0-15 \mathrm{~cm} \\
15-30 \mathrm{~cm}\end{array}$ & $\begin{array}{l}\mathbf{7 . 2 7} \pm \mathbf{0 . 1 8} \\
7.51 \pm 0.16\end{array}$ & $\begin{array}{l}\mathbf{7 . 7 1} \pm \mathbf{0 . 1 4} \\
7.69 \pm 0.16\end{array}$ & $\begin{array}{l}7.87 \pm 0.23 \\
8.16 \pm 0.18\end{array}$ & $\begin{array}{l}7.83 \pm 0.19 \\
8.06 \pm 0.14\end{array}$ & $\begin{array}{l}8.41 \pm 0.08 \\
8.48 \pm 0.03\end{array}$ & $\begin{array}{l}8.48 \pm 0.01 \\
8.46 \pm 0.04\end{array}$ & $\begin{array}{l}7.66 \pm 0.15 \\
7.91 \pm 0.13\end{array}$ & $\begin{array}{l}7.84 \pm 0.11 \\
7.94 \pm 0.11\end{array}$ \\
\hline $\begin{array}{l}0 \\
0\end{array}$ & $\begin{array}{l}\text { Silt }(0.02-0.002 \mathrm{~mm}) \\
\text { Clay }(<0.002 \mathrm{~mm})\end{array}$ & $\begin{array}{l}0-15 \mathrm{~cm} \\
15-30 \mathrm{~cm} \\
0-15 \mathrm{~cm} \\
15-30 \mathrm{~cm} \\
0-15 \mathrm{~cm} \\
15-30 \mathrm{~cm} \\
0-15 \mathrm{~cm} \\
15-30 \mathrm{~cm}\end{array}$ & $\begin{array}{c}67.90 \pm 4.50 \\
70.74 \pm 4.00 \\
12.55 \pm 2.64 \\
10.00 \pm 1.93 \\
11.21 \pm 2.01 \\
10.36 \pm 1.80 \\
8.34 \pm 0.58 \\
8.89 \pm 0.93\end{array}$ & $\begin{array}{c}68.39 \pm 2.13 \\
67.96 \pm 2.53 \\
11.11 \pm 1.32 \\
9.99 \pm 1.41 \\
11.08 \pm 0.99 \\
10.41 \pm 1.30 \\
9.42 \pm 0.88 \\
11.64 \pm 1.25\end{array}$ & $\begin{array}{c}77.93 \pm 2.42 \\
78.48 \pm 3.26 \\
5.22 \pm 1.12 \\
3.03 \pm 0.44 \\
5.82 \pm 1.06 \\
6.79 \pm 1.77 \\
11.03 \pm 1.14 \\
11.69 \pm 1.93\end{array}$ & $\begin{array}{c}80.11 \pm 1.64 \\
82.53 \pm 2.20 \\
4.93 \pm 0.51 \\
3.23 \pm 0.40 \\
4.56 \pm 0.76 \\
3.72 \pm 0.58 \\
10.40 \pm 0.98 \\
10.51 \pm 1.77\end{array}$ & $\begin{array}{c}79.99 \pm 1.18 \\
83.43 \pm 2.16 \\
3.61 \pm 0.55 \\
2.83 \pm 0.84 \\
7.79 \pm 0.68 \\
6.94 \pm 1.45 \\
8.60 \pm 1.14 \\
6.80 \pm 0.74\end{array}$ & $\begin{array}{c}78.44 \pm 2.66 \\
80.56 \pm 2.19 \\
3.93 \pm 0.63 \\
2.04 \pm 0.06 \\
8.69 \pm 0.71 \\
9.11 \pm 1.88 \\
8.95 \pm 2.87 \\
8.29 \pm 2.33\end{array}$ & $\begin{array}{c}73.70 \pm 2.44 \\
75.60 \pm 2.42 \\
8.30 \pm 1.46 \\
6.10 \pm 1.10 \\
8.44 \pm 1.11 \\
8.39 \pm 1.16 \\
9.56 \pm 0.62 \\
9.90 \pm 0.99\end{array}$ & $\begin{array}{c}74.71 \pm 1.63 \\
75.84 \pm 2.02 \\
7.57 \pm 0.88 \\
6.10 \pm 0.94 \\
7.92 \pm 0.81 \\
7.20 \pm 0.90 \\
9.80 \pm 0.64 \\
10.77 \pm 0.99\end{array}$ \\
\hline$\sum_{i}^{e}$ & $\begin{array}{l}0.25-0.05 \mathrm{~mm} \\
0.05-0.02 \mathrm{~mm}\end{array}$ & $\begin{array}{l}0-15 \mathrm{~cm} \\
15-30 \mathrm{~cm} \\
0-15 \mathrm{~cm} \\
15-30 \mathrm{~cm} \\
0-15 \mathrm{~cm} \\
15-30 \mathrm{~cm} \\
0-15 \mathrm{~cm} \\
15-30 \mathrm{~cm} \\
0-15 \mathrm{~cm} \\
15-30 \mathrm{~cm}\end{array}$ & $\begin{array}{c}42.68 \pm 1.55 \\
44.14 \pm 2.41 \\
56.83 \pm 1.48 \\
55.42 \pm 2.37 \\
0.36 \pm 0.07 \\
0.30 \pm 0.03 \\
0.11 \pm 0.02 \\
0.12 \pm 0.02 \\
0.02 \pm 0.01 \\
0.03 \pm 0.01\end{array}$ & $\begin{array}{c}38.60 \pm 0.86 \\
39.42 \pm 1.84 \\
60.91 \pm 0.85 \\
60.11 \pm 1.83 \\
0.35 \pm 0.05 \\
0.33 \pm 0.03 \\
0.12 \pm 0.02 \\
0.12 \pm 0.01 \\
0.03 \pm 0.01 \\
0.03 \pm 0.01\end{array}$ & $\begin{array}{c}38.28 \pm 4.78 \\
48.71 \pm 5.66 \\
61.06 \pm 4.77 \\
50.70 \pm 5.65 \\
0.40 \pm 0.06 \\
0.33 \pm 0.07 \\
0.21 \pm 0.04 \\
0.18 \pm 0.04 \\
0.05 \pm 0.02 \\
0.08 \pm 0.02\end{array}$ & $\begin{array}{c}35.27 \pm 4.24 \\
42.97 \pm 5.11 \\
64.03 \pm 4.29 \\
56.30 \pm 5.14 \\
0.38 \pm 0.09 \\
0.38 \pm 0.12 \\
0.22 \pm 0.08 \\
0.24 \pm 0.10 \\
0.09 \pm 0.04 \\
0.11 \pm 0.07\end{array}$ & $\begin{array}{c}30.76 \pm 3.23 \\
43.92 \pm 4.76 \\
65.63 \pm 3.23 \\
53.89 \pm 5.12 \\
1.44 \pm 0.05 \\
0.92 \pm 0.36 \\
\mathbf{1 . 2 8} \pm \mathbf{0 . 0 4} \\
0.80 \pm 0.32 \\
\mathbf{0 . 9 0} \pm \mathbf{0 . 0 5} \\
0.46 \pm 0.23\end{array}$ & $\begin{array}{c}31.38 \pm 4.62 \\
33.52 \pm 6.35 \\
65.40 \pm 4.50 \\
64.47 \pm 7.18 \\
1.36 \pm 0.07 \\
0.90 \pm 0.35 \\
\mathbf{1 . 1 2} \pm \mathbf{0 . 0 7} \\
0.70 \pm 0.31 \\
\mathbf{0 . 7 4} \pm \mathbf{0 . 0 1} \\
0.42 \pm 0.20\end{array}$ & $\begin{array}{c}39.40 \pm 2.32 \\
46.15 \pm 2.74 \\
59.69 \pm 2.26 \\
53.15 \pm 2.74 \\
0.50 \pm 0.08 \\
0.38 \pm 0.06 \\
0.28 \pm 0.07 \\
0.22 \pm 0.05 \\
0.13 \pm 0.05 \\
0.10 \pm 0.03\end{array}$ & $\begin{array}{c}36.32 \pm 1.98 \\
40.34 \pm 2.50 \\
62.79 \pm 1.97 \\
58.90 \pm 3.06 \\
0.48 \pm 0.08 \\
0.41 \pm 0.07 \\
0.27 \pm 0.07 \\
0.24 \pm 0.06 \\
0.14 \pm 0.05 \\
0.11 \pm 0.04\end{array}$ \\
\hline
\end{tabular}

BD: bulk density; PSD: particle size distribution; PM: proportion of aggregates.

0.25 and $0.25-0.05 \mathrm{~mm}$ sized soil aggregates were significantly correlated with soil PSD and soil $\mathrm{pH}(P<0.01)$. SOC, soil TN and AN contents were significantly positively correlated with soil silt content and significantly negatively correlated with soil sand content $(P<0.01)$. However, no correlations were found between soil TP and AP contents and any of the soil PSD $(P>0.05)$. In addition, SOC, soil $\mathrm{TN}, \mathrm{TP}, \mathrm{AN}$, and AP contents were significantly positively correlated with each other in the alpine grassland.

\section{Discussion}

\subsection{Effect of grazing exclusion on soil properties}

Fencing to exclude livestock has been reported to cause reductions in soil BD in different types of grasslands in the world, such as the upland grassland in northern England (Medina-Roldán et al., 2012) and a semiarid sandy grassland in northern China (Su et al., 2005). Soil BD was slightly lower in the GE plots compared to FG plots of the alpine grassland in Tibet. The elimination of soil trampling by livestock - as well as the high organic matter content, high soil silt and clay content, and the presence of extensive shallowroot systems in the grazing exclusion areas - contributed to a decrease in soil BD (Su et al., 2005; Yuan et al., 2012).

It was found that the soil $\mathrm{pH}$ was lower in non-grazed rangelands compared with grazed rangelands probably because of the addition of livestock urine, which increased soil
$\mathrm{pH}$ largely due to the hydrolysis of urine urea in grazed grassland (Raiesi and Riahi, 2014). However, soil pH was not significantly different between FG and GE grasslands in Tibet (Table 2). This was probably due to the relatively low effect of livestock on soil $\mathrm{pH}$ in this region, which was due to low livestock distributions. The actual averaged stocking rate approximately ranges from 0.16 sheep units $\mathrm{ha}^{-1}$ in the western counties to 2.05 sheep units ha ${ }^{-1}$ in the eastern counties (J. Wu et al., 2013, 2014).

Grazing exclusion had no significant influence on soil PSD in the alpine grassland, and soil sand, silt and clay contents did not differ significantly between FG and GE grasslands. This result was not consistent with the results from the Imam Kandi Rangelands, Iran (Mofidi et al., 2013), and in the sandy rangeland of Inner Mongolia, northern China (Li et al., 2011; Chen et al., 2012), in which grazing exclusion led to greater fine soil particle content and lower coarse sand content due to an increased ability of vegetation to prevent soil erosion and trap windblown fine particles (Chen et al., 2012; H. Wen et al., 2013). This inconsistent result in alpine grassland of Tibet was possibly due to the sparse and dwarf vegetation status in the alpine environment and relatively short grazing exclusion period.

Soil aggregates play a key role in protecting soil organic matter from microbial decomposition (Leifeld and KögelKnabner, 2003). They are dynamic soil properties that tend to respond rapidly to environmental changes; for instance, different land use types would exercise their effects on soil aggregate formation and stabilization in various ways and 

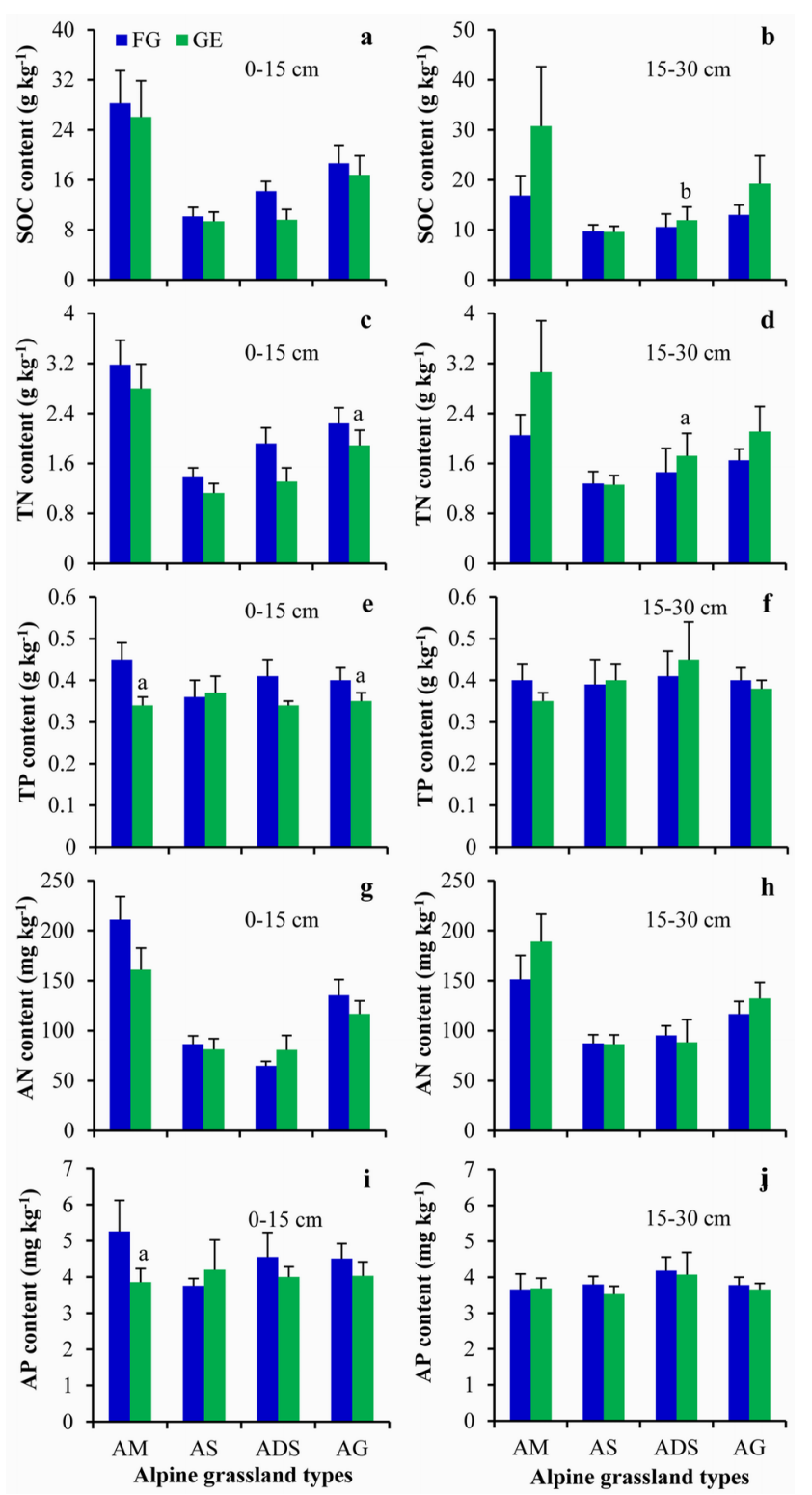

Figure 2. Statistical comparison of soil organic carbon (SOC), total nitrogen (TN), total phosphorus (TP), available nitrogen (AN), and available phosphorus (AP) contents at $0-15$ and $15-30 \mathrm{~cm}$ depth using paired-difference $t$ test $(\alpha=0.05)$ between free-grazing (FG) plots and grazing exclusion (GE) plots. Error bars represent standard errors; AM, AS, ADS, and AG represent alpine meadow, alpine steppe, alpine desert steppe, and alpine grasslands $(\mathrm{AM}+\mathrm{AS}+\mathrm{ADS})$, respectively. a: $P<0.05 ; \mathrm{b}: P<0.01$.

magnitudes (Bongiovanni and Lobartini, 2006). In the alpine grasslands of Tibet, grazing exclusion had no effect on smallsized soil aggregates $(<0.05 \mathrm{~mm})$. However, soil aggregate fractions with $2-0.25$ and $0.25-0.05 \mathrm{~mm}$ were significantly affected by grazing exclusion (Table 2 ).

\subsection{Effect of grazing exclusion on soil nutrients}

In the present study, SOC concentrations at both $0-15$ and $15-30 \mathrm{~cm}$ depth were not affected by grazing exclusion treatment, indicating that changes in grazing regime had little effect on soil organic matter quality in alpine grasslands. Nevertheless, the effects of grazing exclusion on SOC of alpine grassland on the Tibetan Plateau from different studies were shown to be contradictory; in various cases, they have demonstrated a positive effect (Wu et al., 2010; Gao et al., 2011), a negative effect (Hafner et al., 2012; Shi et al., 2013) and a neutral effect (Dong et al., 2012). In fact, these controversies were also reported from different studies on grassland ecosystem restoration in other regions (Mekuria and Aynekulu, 2013; Raiesi and Riahi, 2014). These differences may partly be due to whether grazing pressure exceeds carrying capacity of a site and whether it is sufficiently far beyond that capacity to reach the ecological threshold (Sasaki et al., 2011; X. Wu et al., 2014). Additionally, differences among sites in climatic conditions and/or in grazing seasonality and intensity may be, at least in part, responsible for the observed results (Speed et al., 2014).

SOC contents were significantly positively correlated with soil silt contents and significantly negatively correlated with soil sand content (Table 3). This is because of the amount of soil organic matter associated with silt and clay due to their higher capacity for holding water and nutrients compared to sand (Plante et al., 2006). Thus, soil particle size distributions play an important role in regulating the capacity of a soil to preserve organic matter; for instance, SOC content significantly increased due to grazing exclusion with both higher clay and silt contents and lower sand content in a desert steppe in northwestern China (H. Wen et al., 2013). However, in the present study, both soil particle size distribution and SOC content were unchanged by grazing exclusion treatment in the alpine grasslands.

Grazers can alter $\mathrm{N}$ stocks by either increasing or decreasing $\mathrm{N}$ inputs and $\mathrm{N}$ outputs. Regarding outputs, grazers promote higher $\mathrm{N}$ losses from urine and dung patches but can also stimulate $\mathrm{N}$ retention by decreasing $\mathrm{N}$ losses through greater root allocation. Regarding inputs, grazing can decrease $\mathrm{N}$ inputs by decreasing legume biomass or cover but can also increase $\mathrm{N}$ redeposition from the atmosphere, partially compensating for $\mathrm{N}$ losses (Andrioli et al., 2010; Piñeiro et al., 2010). Significant differences were observed in soil TN concentrations between the GE plots and FG plots in the $0-15 \mathrm{~cm}$ soil layer, indicating that the $\mathrm{N}$ nutrients in the soil surface layer were reduced due to grazing exclusion (Fig. 2). The decrease in soil surface layer TN contents due to grazing exclusion was also found in previous studies on the Tibetan Plateau (Shi et al., 2013). These responses are likely to happen in grazing treatments that maintained a higher carbon input from root, litter and excreta, while an ungrazed treatment would strongly decrease this input and promote aboveground allocation (Kelly et al., 1996). 
Table 2. Results from analysis of covariance (ANCOVA) by the general linear model (GLM) showing $F$ and $P$ values of soil properties and nutrients, in which the fixed factor was grazing treatments (G: free-grazing and grazing exclusion) and soil depth (D: 0-15 and 15-30 cm), while the covariates were growing season temperature (GST) and growing season precipitation (GSP). $P$ values below 0.05 are in bold.

\begin{tabular}{|c|c|c|c|c|c|c|c|c|c|c|}
\hline \multirow[t]{2}{*}{ Soil properties } & \multicolumn{2}{|c|}{ G } & \multicolumn{2}{|c|}{$\mathrm{D}$} & \multicolumn{2}{|c|}{$\mathrm{G} \times \mathrm{D}$} & \multicolumn{2}{|c|}{ GST } & \multicolumn{2}{|c|}{ GSP } \\
\hline & $F$ value & $P$ value & $F$ value & $P$ value & $F$ value & $P$ value & $F$ value & $P$ value & $F$ value & $P$ value \\
\hline $\mathrm{BD}$ & 1.31 & 0.255 & 1.73 & 0.192 & 0.69 & 0.41 & 12.84 & 0.001 & 19.24 & $<0.001$ \\
\hline $\mathrm{pH}$ & 1.93 & 0.168 & 4.68 & $\mathbf{0 . 0 3 3}$ & 0.9 & 0.346 & 83.73 & $<0.001$ & 24.85 & $<0.001$ \\
\hline \multicolumn{11}{|l|}{ PSD } \\
\hline Sand $(2-0.05 \mathrm{~mm})$ & 0.1 & 0.756 & 0.56 & 0.455 & 0.04 & 0.849 & 0.31 & 0.578 & 13.26 & $<0.001$ \\
\hline Silt $(0.05-0.02 \mathrm{~mm})$ & 0.15 & 0.701 & 3.68 & 0.058 & 0.15 & 0.704 & 2.05 & 0.155 & 28.6 & $<0.001$ \\
\hline Silt $(0.02-0.002 \mathrm{~mm})$ & 0.67 & 0.414 & 0.11 & 0.737 & 0.09 & 0.769 & 0.06 & 0.801 & 4.41 & 0.038 \\
\hline Clay $(<0.002 \mathrm{~mm})$ & 0.43 & 0.511 & 0.61 & 0.438 & 0.14 & 0.71 & 0.35 & 0.557 & 0.04 & 0.847 \\
\hline \multicolumn{11}{|l|}{ PM } \\
\hline $2-0.25 \mathrm{~mm}$ & 4.18 & 0.043 & 6.15 & 0.015 & 0.39 & 0.533 & 22.36 & $<0.001$ & 0.01 & 0.944 \\
\hline $0.25-0.05 \mathrm{~mm}$ & 4.05 & 0.047 & 5.62 & 0.02 & 0.36 & 0.55 & 19.03 & $<0.001$ & 0.126 & 0.723 \\
\hline $0.05-0.02 \mathrm{~mm}$ & 0.01 & 0.947 & 2.26 & 0.136 & 0.16 & 0.691 & 18.92 & $<0.001$ & 11.17 & 0.001 \\
\hline $0.02-0.002 \mathrm{~mm}$ & 0.01 & 0.935 & 0.93 & 0.337 & 0.05 & 0.829 & 21.88 & $<0.001$ & 24.4 & $<0.001$ \\
\hline$<0.002 \mathrm{~mm}$ & 0.04 & 0.851 & 0.82 & 0.367 & 0.02 & 0.896 & 23.28 & $<0.001$ & 26.18 & $<0.001$ \\
\hline SOC & 0.41 & 0.524 & 0.22 & 0.64 & 1.38 & 0.243 & 0.09 & 0.764 & 12.75 & 0.001 \\
\hline TN & 0.05 & 0.818 & 0.53 & 0.467 & 2.46 & 0.12 & 0.83 & 0.364 & 19.18 & $<0.001$ \\
\hline $\mathrm{TP}$ & 1.89 & 0.172 & 0.29 & 0.59 & 0.53 & 0.469 & 11.98 & 0.001 & 2.44 & 0.121 \\
\hline AN & 0.02 & 0.904 & 0.02 & 0.892 & 1.99 & 0.161 & 0.1 & 0.758 & 43.26 & $<0.001$ \\
\hline $\mathrm{AP}$ & 0.92 & 0.34 & 3.06 & 0.08 & 0.34 & 0.56 & 0.69 & 0.41 & 0.09 & 0.77 \\
\hline
\end{tabular}

BD: bulk density; PSD: particle size distribution; PM: proportion of aggregates; SOC: soil organic carbon; TN: total nitrogen; TP: total phosphorus; AN: available nitrogen; AP: available phosphorus.

Table 3. Pearson's correlation coefficients among soil property and nutrient indicators of alpine grasslands and their significance levels.

\begin{tabular}{|c|c|c|c|c|c|c|c|c|c|c|c|c|c|c|c|}
\hline $\begin{array}{l}\text { Soil } \\
\text { properties }\end{array}$ & $\mathrm{BD}$ & Sand & Silt1 & Silt2 & Clay & $\mathrm{PM}_{1}$ & $\mathrm{PM}_{2}$ & $\mathrm{PM}_{3}$ & $\mathrm{PM}_{4}$ & $\mathrm{PM}_{5}$ & $\mathrm{pH}$ & SOC & $\mathrm{TN}$ & TP & AN \\
\hline Sand & $0.42^{\mathrm{b}}$ & & & & & & & & & & & & & & \\
\hline Silt1 & $-0.36^{\mathrm{b}}$ & $-0.83^{b}$ & & & & & & & & & & & & & \\
\hline Silt2 & $0.43^{\mathrm{b}}$ & $-0.92^{b}$ & $-0.77^{\mathrm{b}}$ & & & & & & & & & & & & \\
\hline Clay & -0.06 & $-0.37^{b}$ & -0.15 & 0.12 & & & & & & & & & & & \\
\hline $\mathrm{PM}_{1}$ & $0.25^{\mathrm{a}}$ & $0.31^{\mathrm{b}}$ & -0.14 & $-0.28^{\mathrm{b}}$ & $-0.29^{b}$ & & & & & & & & & & \\
\hline $\mathrm{PM}_{2}$ & $-0.25^{\mathrm{b}}$ & $-0.32^{\mathrm{b}}$ & 0.14 & $0.28^{\mathrm{b}}$ & $0.30^{\mathrm{b}}$ & $-0.99^{b}$ & & & & & & & & & \\
\hline $\mathrm{PM}_{3}$ & -0.06 & -0.05 & 0.02 & 0.14 & -0.06 & -0.17 & 0.10 & & & & & & & & \\
\hline $\mathrm{PM}_{4}$ & 0.04 & 0.16 & $-0.20^{\mathrm{a}}$ & -0.04 & -0.08 & -0.09 & 0.02 & $0.95^{\mathrm{b}}$ & & & & & & & \\
\hline $\mathrm{PM}_{5}$ & 0.04 & $0.20^{\mathrm{a}}$ & $-0.22^{\mathrm{a}}$ & -0.06 & -0.14 & -0.06 & -0.01 & $0.91^{\mathrm{b}}$ & $0.98^{\mathrm{b}}$ & & & & & & \\
\hline $\mathrm{pH}$ & 0.05 & $0.31^{b}$ & $-0.54^{b}$ & $-0.25^{\mathrm{b}}$ & $0.22^{\mathrm{a}}$ & $-0.34^{b}$ & $0.32^{\mathrm{b}}$ & $0.20^{\mathrm{a}}$ & $0.26^{\mathrm{b}}$ & $0.27^{\mathrm{b}}$ & & & & & \\
\hline SOC & $-0.68^{b}$ & $-0.33^{b}$ & $0.35^{\mathrm{b}}$ & $0.35^{\mathrm{b}}$ & -0.06 & -0.06 & 0.07 & -0.22 & -0.12 & -0.12 & -0.15 & & & & \\
\hline $\mathrm{TN}$ & $-0.69^{b}$ & $-0.38^{b}$ & $0.39^{\mathrm{b}}$ & $0.39^{\mathrm{b}}$ & -0.03 & -0.08 & 0.08 & -0.01 & -0.13 & -0.13 & -0.14 & $0.97^{\mathrm{b}}$ & & & \\
\hline TP & -0.16 & -0.10 & 0.07 & 0.05 & 0.10 & $0.22^{\mathrm{a}}$ & $-0.22^{\mathrm{a}}$ & -0.04 & -0.06 & -0.04 & -0.16 & $0.19^{\mathrm{a}}$ & $0.25^{\mathrm{b}}$ & & \\
\hline AN & $-0.62^{b}$ & $-0.37^{b}$ & $0.46^{\mathrm{b}}$ & $0.39^{\mathrm{b}}$ & -0.13 & 0.11 & -0.10 & -0.11 & -0.21 & -0.21 & $-0.35^{\mathrm{b}}$ & $0.78^{b}$ & $0.79^{\mathrm{b}}$ & $0.26^{\mathrm{b}}$ & \\
\hline AP & $-0.39^{b}$ & -0.16 & 0.08 & 0.17 & 0.08 & 0.05 & -0.05 & 0.03 & -0.02 & -0.01 & -0.06 & $0.49^{\mathrm{b}}$ & $0.51^{b}$ & $0.46^{\mathrm{b}}$ & $0.50^{\mathrm{b}}$ \\
\hline
\end{tabular}

${ }^{\text {a }} P<0.05,{ }^{\text {b }} P<0.01$. BD: bulk density; Sand: sand $(2-0.05 \mathrm{~mm})$; Silt1: silt $(0.05-0.02 \mathrm{~mm})$; Silt2: silt $(0.02-0.002 \mathrm{~mm})$; Clay: clay $(<0.002 \mathrm{~mm})$; PSD: particle size distribution; PM: proportion of aggregates $\left(\mathrm{PM}_{1}: 2-0.25 \mathrm{~mm} ; \mathrm{PM}_{2}: 0.25-0.05 \mathrm{~mm} ; \mathrm{PM}_{3}: 0.05-0.02 \mathrm{~mm} ; \mathrm{PM}_{4}: 0.02-0.002 \mathrm{~mm} ; \mathrm{PM}_{5}:<0.002 \mathrm{~mm}\right)$; SOC: soil organic carbon; TN: total nitrogen; TP: total phosphorus; AN: available nitrogen; AP: available phosphorus. 
Grazing exclusion substantially improved soil N availability in the temperate steppe in northern China, which suggests that there are positive effects of ecological restoration on soil $\mathrm{N}$ availability (Wang et al., 2010; Chen et al., 2012). However, this improvement was not found in alpine grasslands with ecological restoration by grazing exclusion (Fig. 2), and an earlier study also showed no significant effect of grazing exclusion on soil $\mathrm{N}$ availability in tundra ecosystems (Stark et al., 2015). This may be because soil $\mathrm{N}$ availability is the balance of multiple ecological processes - such as nitrification, mineralization, denitrification, nitrate leaching, and plant uptake - and relatively short grazing exclusion time in alpine grasslands did not change this balance.

Soil TP contents at a depth of $0-15 \mathrm{~cm}$ significantly decreased by $12.5 \%$ in GE grasslands. The reduction of total $\mathrm{P}$ in soil surface layer due to grazing exclusion may be contributed by the absence of inputs of animal excreta, which has long been recognized as an important pathway in the $\mathrm{P}$ cycle in grazed pasture, and higher soil $\mathrm{P}$ uptake by vegetation (Chaneton and Lavado, 1996). Soil AP was not affected by grazing exclusion in alpine grasslands, which is consistent with research in a temperate subhumid grassland in Argentina that found that grazing did not affect soil available nutrients, although it did accelerate soil phosphorus cycling rates (Chaneton and Lavado, 1996).

\subsection{The effect of climate factors}

Our results from ANCOVA analysis indicated that grazing exclusion almost had no effect on soil properties and nutrients. However, climate conditions during the growing season played an important role in controlling the soil quality status of alpine grasslands in Tibet because GST and/or GSP were found to have significant effects on almost all soil property and nutrient indicators (Table 2). Therefore, the soil properties and nutrients of alpine grasslands in Tibet were primarily driven by the climate gradient distributions but not by grazing exclusion treatments. Climatic factors, including temperature and precipitation, can directly or indirectly impact soil quality status by controlling soil environmental conditions, soil weathering process, soil microbe and enzyme activities, substrate availability, translocation of dissolved ions, and so on (Barthold et al., 2013; Clarholm and Skyllberg, 2013; Chen et al., 2015).

Soil BD was significantly impacted by both temperature and precipitation in this alpine region, which may be a result of the expansion and compression of the soil matrix due to changing of freezing and thawing processes caused by climate (Henry, 2007; Yang et al., 2010). Soil pH affected by the climate factors has been found in many natural ecosystems (Barton et al., 1994), which is also confirmed in alpine grasslands in Tibet in the present study. Soil aggregate is a dynamic soil property, which varies over time, partially depending on climatic processes (Dimoyiannis, 2009). In alpine grasslands, proportions of soil aggregates were gener- ally influenced by both GST and GSP. Similar findings were also reported by Rillig et al. (2002), who found that increasing temperature could decrease soil aggregate water stability by stimulating the role of arbuscular mycorrhizal fungi in soil aggregation in an annual grassland in northern California, USA, and by Dimoyiannis (2009), who reported that total monthly precipitation and mean monthly air temperature strongly correlated with seasonal soil aggregate stability in the Thessaly Plain, central Greece.

We found that soil nutrients - including SOC, soil TN and AN contents - were significantly affected by GSP (Table 2). Therefore, precipitation during the growing season played an important role in controlling the soil $\mathrm{C}$ and $\mathrm{N}$ contents of alpine grasslands in Tibet. The potential changes in precipitation are identified as vital aspects of regional climate change, which can alter the distribution and dynamics of water availability and subsequently alter soil biogeochemical processes at the ecosystem level (Cerdà and Lavée, 1999; Hao et al., 2013). The precipitation could play the most prominent role in grassland ecosystem $\mathrm{C}$ and $\mathrm{N}$ dynamics, especially for arid and semiarid ecosystems, through their influence on plant productivity (Robertson et al., 2009), soil carbon cycle processes (Hao et al., 2013), and soil N transformations (Cregger et al., 2014). There is increasing evidence to show that the total amount of precipitation and the altered precipitation patterns control the dynamics of net primary production, soil organic carbon storage, carbon dioxide fluxes, and soil $\mathrm{N}$ cycling and transformations of alpine grassland ecosystems on the Tibetan Plateau (Zhuang et al., 2010; Zhang et al., 2012; Shen et al., 2015).

\section{Conclusions}

In an attempt to alleviate the problem of grassland degradation on the Tibetan Plateau, China's state and local authorities have recently initiated a program called the retirelivestock-and-restore-grassland project, in which fencing to exclude grazers has been used as an approach for restoring degraded grasslands. In the present study, we conducted a field survey to evaluate the effectiveness of the grazing exclusion on soil properties and nutrients in restoring degraded alpine grasslands in Tibet. In general, grazing exclusion by fencing had no impact on most soil properties and nutrients, and it even caused a considerable decrease in soil TN and $\mathrm{TP}$ in the soil surface layer of alpine grassland ecosystems, including alpine meadow, alpine steppe, and alpine desert steppe. Nevertheless, climate conditions during the growing season played an important role in controlling the soil quality status of alpine grasslands.

Therefore, at present, the restoration policy is not effective for improving the soil quality of degraded alpine grassland in Tibet. It is noted that the results of the present study come from short-term (6-8 years) grazing exclusion, while the restoration of the soil quality status of degraded grassland 
is a long-term evolutionary process. Thus, it is still uncertain whether grazing exclusion will improve soil properties and nutrients or not if this policy is continuously implemented for decades. Long-term observations and continued research are still necessary to assess the ecological effects of the grazing exclusion management strategy on soil quality of degraded alpine grasslands in Tibet. In addition, because the soil properties and nutrients of alpine grasslands in Tibet were primarily driven by the climate factors, the potential shift of climate conditions should be considered when recommending any policy designed for the restoration of degraded soil in alpine grasslands in the future.

Acknowledgements. This study was supported by the National Natural Science Foundation of China (41371267 and 41201053), the Action Plan of the Chinese Academy of Sciences for Western Development (KZCX2-XB3-08), and the 135 Strategic Program of the Institute of Mountain Hazards and Environment (SDS-1351203-03).

Edited by: A. Cerdà

\section{References}

Alvarenga, P., Palma, P., de Varennes, A., and Cunha-Queda, A. C.: A contribution towards the risk assessment of soils from the São Domingos Mine (Portugal): Chemical, microbial and ecotoxicological indicators, Environ. Pollut., 161, 50-56, 2012.

Andrioli, R. J., Distel, R. A., and Didoné, N. G.: Influence of cattle grazing on nitrogen cycling in soils beneath Stipa tenuis, native to central Argentina, J. Arid Environ., 74, 419-422, 2010.

Bai, X. Y., Wang, S. J., and Xiong, K. N.: Assessing spatialtemporal evolution processes of karst rocky desertification land: Indications for restoration strategies, Land Degrad. Dev., 24, 4756, 2013.

Barthold, F. K., Wiesmeier, M., Breuer, L., Frede, H. G., Wu, J., and Blank, F. B.: Land use and climate control the spatial distribution of soil types in the grasslands of Inner Mongolia, J. Arid Environ., 88, 194-205, 2013.

Barton, D., Hope, D., Billett, M. F., and Cresser, M. S.: Sulphate adsorption capacity and $\mathrm{pH}$ of upland podzolic soils in Scotland: Effects of parent material, texture and precipitation chemistry, Appl. Geochem., 9, 127-139, 1994.

Bongiovanni, M. D. and Lobartini, J. C.: Particulate organic matter, carbohydrate, humic acid contents in soil macro- and microaggregates as affected by cultivation, Geoderma, 136, 660-665, 2006.

Brevik, E. C., Cerdà, A., Mataix-Solera, J., Pereg, L., Quinton, J. N., Six, J., and Van Oost, K.: The interdisciplinary nature of SOIL, SOIL, 1, 117-129, doi:10.5194/soil-1-117-2015, 2015.

Campbell, C. D., Seiler, J. R., Wiseman, P. E., Strahm, B. D., and Munsell, J. F.: Soil carbon dynamics in residential lawns converted from appalachian mixed oak stands, Forests, 5, 425-438, 2014.

Cao, Y. Z., Wang, X. D., Lu, X. Y., Yan, Y., and Fan, J. H.: Soil organic carbon and nutrients along an alpine grassland transect across Northern Tibet, J. Mt. Sci., 10, 564-573, 2013.
Cerdà, A. and Lavée, H.: The effect of grazing on soil and water losses under arid and Mediterranean climates, Implications for desertification, Pirineos, 153-154, 159-174, 1999.

Cerdà, A., Giménez-Morera, A., and Bodí, M. B.: Soil and water losses from new citrus orchards growing on sloped soils in the western Mediterranean basin, Earth Surf. Proc. Land., 34, 18221830, 2009.

Chaneton, R. S. and Lavado, R. S.: Soil nutrients and salinity after long-term grazing exclusion in a Flooding Pampa grassland, J. Range Manage, 49, 182-187, 1996.

Chen, D., Cheng, J., Chu, P., Hu, S., Xie, Y., Tuvshintogtokh, I., and Bai, Y.: Regional-scale patterns of soil microbes and nematodes across grasslands on the Mongolian plateau: relationships with climate, soil, and plants, Ecography, 38, 622-631, 2015.

Chen, Y., Li, Y., Zhao, X., Awada, T., Shang, W., and Han, J.: Effects of grazing exclusion on soil properties and on ecosystem carbon and nitrogen storage in a sandy rangeland of Inner Mongolia, northern China, Environ. Manage., 50, 622-632, 2012.

Clarholm, M. and Skyllberg, U.: Translocation of metals by trees and fungi regulates $\mathrm{pH}$, soil organic matter turnover and nitrogen availability in acidic forest soils, Soil Biol. Biochem., 63, 142153, 2013.

Costa, C., Papatheodorou, E. M., Monokrousos, N., and Stamou, G. P.: Spatial variability of soil organic C, inorganic N and extractable $\mathrm{P}$ in a Mediterranean grazed area, Land Degrad. Dev., 26, 103-109, 2015.

Cregger, M. A., McDowell, N. G., Pangle, R. E., Pockman, W. T., and Classen, A. T.: The impact of precipitation change on nitrogen cycling in a semi-arid ecosystem, Funct. Ecol., 28, 15341544, 2014.

Dai, F., Su, Z., Liu, S., and Liu, G.: Temporal variation of soil organic matter content and potential determinants in Tibet, China, Catena, 85, 288-294, 2011.

Dimoyiannis, D.: Seasonal soil aggregate stability variation in relation to rainfall and temperature under Mediterranean conditions, Earth Surf. Proc. Land., 34, 860-866, 2009.

Dong, S. K., Wen, L., Li, Y. Y., Wang, X. X., Zhu, L., and Li, X. Y.: Soil-Quality Effects of grassland degradation and restoration on the Qinghai-Tibetan Plateau, Soil Sci. Soc. Am. J., 76, 22562264, 2012.

Gao, Y., Zeng, X., Schumann, M., and Chen, H.: Effectiveness of exclosures on restoration of degraded alpine meadow in the eastern Tibetan Plateau, Arid Land Res. Manag., 25, 164-175, 2011.

García-Orenes, F., Roldán, A., Mataix-Solera, J., Cerdà, A., Campoy, M., Arcenegui, V., and Caravaca, F.: Soil structural stability and erosion rates influenced by agricultural management practices in a semi-arid Mediterranean agro-ecosystem, Soil Use Manage., 28, 571-579, 2012.

Gonzales, E. K. and Clements, D. R.: Plant community biomass shifts in response to mowing and fencing in invaded oak meadows with non-native grasses and abundant ungulates, Restor. Ecol., 18, 753-761, 2010.

Greenwood, K. L. and McKenzie, B. M.: Grazing effects on soil physical properties and the consequences for pastures: a review, Aust. J. Exp. Agr., 41, 1231-1250, 2001.

Hafner, S., Unteregelsbacher, S., Seeber, E., Lena, B., Xu, X., Li, X., Guggenberger, G., Miehe. G., and Kuzyakov, Y.: Effect of grazing on carbon stocks and assimilate partitioning in a Ti- 
betan montane pasture revealed by ${ }^{13} \mathrm{CO}_{2}$ pulse labeling, Global Change Biol., 18, 528-538, 2012.

Hao, Y., Kang, X., Wu, X., Cui, X, Liu, W., Zhang, H., Li, Y., Wang, Y., $\mathrm{Xu}, \mathrm{Z}$., and Zhao, H.: Is frequency or amount of precipitation more important in controlling $\mathrm{CO}_{2}$ fluxes in the 30 -yearold fenced and the moderately grazed temperate steppe?, Agr. Ecosyst. Environ., 171, 63-71, 2013.

Harris, R. B.: Rangeland degradation on the Qinghai-Tibetan plateau: A review of the evidence of its magnitude and causes, J. Arid Environ., 74, 1-12, 2010.

Haynes, A. G., Schütz, M., Buchmann, N., Page-Dumroese, D. S., Busse, M. D., and Risch, A.C.: Linkages between grazing history and herbivore exclusion on decomposition rates in mineral soils of subalpine grasslands, Plant Soil, 374, 579-591, 2014.

Henry, H. A. L.: Soil freeze-thaw cycle experiments: Trends, methodological weaknesses and suggested improvements, Soil Biol. Biochem., 39, 977-986, 2007.

Hoshino, A., Tamura, K., Fujimaki, H., Asano, M., Ose, K., and Higashi, T.: Effects of crop abandonment and grazing exclusion on available soil water and other soil properties in a semi-arid Mongolian grassland, Soil Till. Res., 105, 228-235, 2009.

Keesstra, S. D., Geissen, V., Mosse, K., Piiranen, S., Scudiero, E., Leistra, M., and van Schaik, L.: Soil as a filter for groundwater quality, Curr. Opin. Environ. Su., 4, 507-516, 2012.

Keesstra, S. D., Maroulis, J., Argaman, E., Voogt, A., and Wittenberg, L.: Effects of controlled fire on hydrology and erosion under simulated rainfall, Cuad. Invest. Geogr., 40, 269-293, 2014.

Kelly, R. H., Burke, I. C., and Lauenroth, W. K.: Soil organic matter and nutrient availability responses to reduced plant inputs in shortgrass steppe, Ecology, 77, 2516-2527, 1996.

Land Management Bureau of Tibet: Grassland resources in Tibet Autonomous Region, Sciences Press, Beijing, China, 1994 (in Chinese).

Leifeld, J. and Kögel-Knabner, I.: Microaggregates in agricultural soils and their size distribution determined by X-ray attenuation, Eur. J. Soil Sci., 54, 167-174, 2003.

Li, Y., Dong, S., Wen, L., Wang, X., and Wu, Y.: The effects of fencing on carbon stocks in the degraded alpine grasslands of the Qinghai-Tibetan Plateau, J. Environ. Manage., 128, 393-399, 2013.

Li, Y., Zhao, H., Zhao, X., Zhang, T., Li, Y., and Cui, J.: Effects of grazing and livestock exclusion on soil physical and chemical properties in desertified sandy grassland, Inner Mongolia, northern China, Environ. Earth Sci., 63, 771-783, 2011.

Liu, G. S.: Soil physical and chemical analysis \& description of soil profiles, Chinese Standard Press, Beijing, China, 1996 (in Chinese).

Luan, J., Cui, L., Xiang, C., Wu, J., Song, H., Ma, Q., and Hu, Z.: Different grazing removal exclosures effects on soil $\mathrm{C}$ stocks among alpine ecosystems in east Qinghai-Tibet Plateau, Ecol. Eng., 64, 262-268, 2014.

Medina-Roldán, E., Paz-Ferreiro, J., and Bardgett, R. D.: Grazing exclusion affects soil and plant communities, but has no impact on soil carbon storage in an upland grassland, Agr. Ecosyst. Environ., 149, 118-123, 2012.

Mekonnen, M., Keesstra, S. D., Baartman, J. E., Ritsema, C. J., and Melesse, A. M.: Evaluating sediment storage dams: structural off-site sediment trapping measures in northwest Ethiopia, Cuad. Invest. Geogr., 41, 7-22, 2015 a.
Mekonnen, M., Keesstra, S. D., Stroosnijder, L., Baartman, J. E. M., and Maroulis, J.: Soil conservation through sediment trapping: A review, Land Degrad. Dev., 26, 544-556, 2015 b.

Mekuria, W. and Aynekulu, E.: Exclosure land management for restoration of the soils in degraded communal grazing lands in northern Ethiopia, Land Degrad. Dev., 24, 528-538, 2013.

Mofidi, M., Jafari, M., Tavili, A., Rashtbari, M., and Alijanpour, A.: Grazing exclusion effect on soil and vegetation properties in Imam Kandi Rangelands, Iran, Arid Land Res. Manag., 27, 3240, 2013.

Novara, A., Gristina, L., Saladino, S. S., Santoro, A., and Cerdà, A.: Soil erosion assessment on tillage and alternative soil managements in a Sicilian vineyard, Soil Till. Res., 117, 140-147, 2011.

Novara, A., Gristina, L., Guaitoli, F., Santoro, A., and Cerdè, A.: Managing soil nitrate with cover crops and buffer strips in Sicilian vineyards, Solid Earth, 4, 255-262, doi:10.5194/se-4-2552013, 2013.

Olsen, S. R., Cole, C. V., Watanabe, F., and Dean, L. A.: Estimation of available phosphorus in soils by extraction with sodium bicarbonate, USDA Circular No. 939, 19 pp., USA, 1954.

Papanastasis, V. P., Bautista, S., Chouvardas, D., Mantzanas, K., Papadimitriou, M., Mayor, A. G., Koukioumi, P., Papaioannou, A., and Vallejo, V.: Comparative assessment of goods and services provided by grazing regulation and reforestation in degraded Mediterranean rangelands, Land Degrad. Dev., doi:10.1002/ldr.2368, online first, 2015.

Parras-Alcántara, L., Martín-Carrillo, M., and Lozano-García, B.: Impacts of land use change in soil carbon and nitrogen in a Mediterranean agricultural area (Southern Spain), Solid Earth, 4, 167-177, doi:10.5194/se-4-167-2013, 2013.

Pereira, P., Cerdà, A., Úbeda, X., Mataix-Solera, J., Martin, D., Jordán, A., and Burguet, M.: Spatial models for monitoring the spatio-temporal evolution of ashes after fire - a case study of a burnt grassland in Lithuania, Solid Earth, 4, 153-165, doi:10.5194/se-4-153-2013, 2013.

Piñeiro, G., Paruelo, J. M., Oesterheld, M., and Jobbágy, E. G.: Pathways of grazing effects on soil organic carbon and nitrogen, Rangeland Ecol. Manag., 63, 109-119, 2010.

Plante, A. F., Conant, R. T., Stewart, C. E., Paustian, K., and Six, J.: Impact of soil texture on the distribution of soil organic matter in physical and chemical fractions, Soil Sci. Soc. Am. J., 70, 287 296, 2006.

Pulido-Fernández, M., Schnabel, S., Lavado-Contador, J. F., Mellado, I. M., and Pérez, R. O.: Soil organic matter of Iberian open woodland rangelands as influenced by vegetation cover and land management, Catena, 109, 13-24, 2013.

Qu, F., Yu, J., Du, S., Li, Y., Lv, X., Ning, K., Wu, H., and Meng, L.: Influences of anthropogenic cultivation on $\mathrm{C}, \mathrm{N}$ and $\mathrm{P}$ stoichiometry of reed-dominated coastal wetlands in the Yellow River Delta, Geoderma, 235-236, 227-232, 2014.

Raiesi, F. and Riahi, M.: The influence of grazing exclosure on soil $\mathrm{C}$ stocks and dynamics, and ecological indicators in upland arid and semi-arid rangelands, Ecol. Indic., 41, 145-154, 2014.

Rillig, M. C., Wright, S. F., Shaw, M. R., and Field, C. B.: Artificial climate warming positively affects arbuscular mycorrhizae but decreases soil aggregate water stability in an annual grassland, Oikos, 97, 52-58, 2002. 
Roa-Fuentes, L. L., Martínez-Garza, C., Etchevers, J., and Campo, J.: Recovery of soil $\mathrm{C}$ and $\mathrm{N}$ in a tropical pasture: Passive and active restoration, Land Degrad. Dev., 26, 201-210, 2015.

Robertson, T. R., Bell, C. W., Zak, J. C., and Tissue, D. T.: Precipitation timing and magnitude differentially affect aboveground annual net primary productivity in three perennial species in a Chihuahuan Desert grassland, New Phytol., 181, 230-242, 2009.

Sasaki, T., Okubo, S., Okayasu, T., Jamsran, U., Ohkuro, T., and Takeuchi, K.: Indicator species and functional groups as predictors of proximity to ecological thresholds in Mongolian rangelands, Plant Ecol., 212, 327-342, 2011.

Schultz, N. L., Morgan, J. W., and Lunt, I. D.: Effects of grazing exclusion on plant species richness and phytomass accumulation vary across a regional productivity gradient, J. Veg. Sci., 22, 130142,2011

Shen, Z. X., Li, Y. L., and Fu, G.: Response of soil respiration to short-term experimental warming and precipitation pulses over the growing season in an alpine meadow on the Northern Tibet, Appl. Soil Ecol., 90, 35-40, 2015.

Shi, F. X., Hao, Z. C., and Shao, Q. X.: The analysis of water vapor budget and its future change in the Yellow-Huai-Hai region of China, J. Geophys. Res.-Atmos., 119, 10702-10719, 2014.

Shi, X. M., Li, X. G., Li, C. T., Zhao, Y., Shang, Z. H., and Ma, Q.: Grazing exclusion decreases soil organic $\mathrm{C}$ storage at an alpine grassland of the Qinghai-Tibetan Plateau, Ecol. Eng., 57, 183$187,2013$.

Shrestha, G. and Stahl, P. D.: Carbon accumulation and storage in semi-arid sagebrush steppe: Effects of long-term grazing exclusion, Agr. Ecosyst. Environ., 125, 173-181, 2008.

Speed, J. D. M., Martinsen, V., Mysterud, A., Mulder, J., Holand, $\varnothing$., and Austrheim, G.: Long-term increase in aboveground carbon stocks following exclusion of grazers and forest establishment in an alpine ecosystem, Ecosystems, 17, 1138-1150, 2014.

Stark, S., Männistö, M. K., and Eskelinen, A.: When do grazers accelerate or decelerate soil carbon and nitrogen cycling in tundra? A test of theory on grazing effects in fertile and infertile habitats, Oikos, 124, 593-602, 2015.

Su, Y. Z., Li, Y. L., Cui, J. Y., and Zhao, W. Z.: Influences of continuous grazing and livestock exclusion on soil properties in a degraded sandy grassland, Inner Mongolia, northern China, Catena, 59, 267-278, 2005.

Su, Z. A., Zhang, J. H., and Nie, X. J.: Effect of soil erosion on soil properties and crop yields on slopes in the Sichuan Basin, China, Pedosphere, 20, 736-746, 2010.

Tarhouni, M., Ben Hmida, W., and Neffati, M.: Long-term changes in plant life forms as a consequence of grazing exclusion under arid climatic conditions, Land Degrad. Dev., doi:10.1002/ldr.2407, online first, 2015.

Tejada, M. and Benítez, C.: Effects of crushed maize straw residues on soil biological properties and soil restoration, Land Degrad. Dev., 25, 501-509, 2014.

Wang, C., Han, X., and Xing, X.: Effects of grazing exclusion on soil net nitrogen mineralization and nitrogen availability in a temperate steppe in northern China, J. Arid Environ., 74, $1287-$ 1293, 2010.

Wang, S., Wang, X., Guo, H., Fan, W., Lv, H., and Duan, R.: Distinguishing the importance between habitat specialization and dispersal limitation on species turnover, Ecol. Evol., 3, 3545-3553, 2013.
Wei, D., Xu, R., Wang, Y., Wang, Y., Liu, Y., and Yao, T.: Responses of $\mathrm{CO}_{2}, \mathrm{CH}_{4}$ and $\mathrm{N}_{2} \mathrm{O}$ fluxes to livestock exclosure in an alpine steppe on the Tibetan Plateau, China, Plant Soil, 359, 45-55, 2012.

Wen, L., Dong, S. K., Li, Y. Y., Sherman, R., Shi, J. J., Liu, D. M., Wang, Y. L., Ma, Y. S., and Zhu, L.: The effects of biotic and abiotic factors on the spatial heterogeneity of alpine grassland vegetation at a small scale on the Qinghai-Tibet Plateau (QTP), China, Environ. Monit. Assess., 185, 8051-8064, 2013.

Wen, H., Niu, D., Fu, H., and Kang, J.: Experimental investigation on soil carbon, nitrogen, and their components under grazing and livestock exclusion in steppe and desert steppe grasslands, Northwestern China, Environ. Earth Sci., 70, 3131-3141, 2013.

Wu, G. L., Liu, Z. H., Zhang, L., Chen, J. M., and Hu, T. M.: Longterm fencing improved soil properties and soil organic carbon storage in an alpine swamp meadow of western China, Plant Soil, 332, 331-337, 2010.

Wu, J., Zhang, X., Shen, Z., Shi, P., Xu, X., and Li, X.: Grazingexclusion effects on aboveground biomass and water-use efficiency of alpine grasslands on the northern Tibetan Plateau, Rangeland Ecol. Manag., 66, 454-461, 2013.

Wu, J., Shen, Z., and Zhang, X.: Precipitation and species composition primarily determine the diversity-productivity relationship of alpine grasslands on the Northern Tibetan Plateau, Alpine Bot., 124, 13-25, 2014.

Wu, X., Li, Z., Fu, B., Lu, F., Wang, D., Liu, H., and Liu, G.: Effects of grazing exclusion on soil carbon and nitrogen storage in semiarid grassland in Inner Mongolia, China, Chin. Geogra. Sci., 24, 479-487, 2014.

Yan, Y. and Lu, X.: Is grazing exclusion effective in restoring vegetation in degraded alpine grasslands in Tibet, China?, PeerJ, 3, e1020, doi:10.7717/peerj.1020, 2015.

Yang, M., Nelson, F. E., Shiklomanov, N. I., Guo, D., and Wan, G.: Permafrost degradation and its environmental effects on the Tibetan Plateau: A review of recent research, Earth-Sci. Rev., 103, 31-44,

Yuan, J., Ouyang, Z., Zheng, H., and Xu, W.: Effects of different grassland restoration approaches on soil properties in the southeastern Horqin sandy land, northern China, Appl. Soil Ecol., 61, 34-39, 2012.

Zhang, S., Chen, D., Sun, D., Wang, X., Smith, J. L., and Du, G.: Impacts of altitude and position on the rates of soil nitrogen mineralization and nitrification in alpine meadows on the eastern Qinghai-Tibetan Plateau, China, Biol. Fert. Soils, 48, 393-400, 2012.

Zhao, G., Mu, X., Wen, Z., Wang, F., and Gao, P.: Soil erosion, conservation, and eco-environment changes in the loess plateau of China, Land Degrad. Dev., 24, 499-510, 2013.

Zhuang, Q., He, J., Lu, Y., Ji, L., Xiao, J., and Luo, T.: Carbon dynamics of terrestrial ecosystems on the Tibetan Plateau during the 20th century: an analysis with a process-based biogeochemical model, Global Ecol. Biogeogr., 19, 649-662, 2010. 